\title{
Adaptation of the Differentiation of Self Inventory Short Form (DSI-SF) to Turkish: Validity and Reliability Study
}

\author{
Yusuf SARIKAYA*a ${ }^{*}$, Mehmet BOYACI ${ }^{\mathrm{b}}$, Tahsin ILHAN ${ }^{\mathrm{c}}$, Abdullah ALDEMIR $^{\mathrm{d}}$
}

\begin{tabular}{l} 
Article Info \\
\hline DOI: $10.14686 /$ buefad.364196 \\
\hline Article History: \\
Received: $\quad 09.12 .2017$ \\
Accepted: $\quad 15.04 .2018$ \\
Published: $\quad 30.06 .2018$ \\
\hline Keywords: \\
Differentiation of self, \\
Family therapy, \\
Scale adaptation. \\
\hline Article Type: \\
Research Article \\
\end{tabular}

\begin{abstract}
The aim of this study is to adapt the Differentiation of Self Inventory Short Form to Turkish and to conduct validity and reliability analyzes. The research group consisted of university students and adults aged from 20 to $64(\bar{x}=30.69$, sd $=$ 9.56). The structure of the scale was validated by confirmatory factor analysis and the significance of the difference between the $27 \%$ upper and lower groups. Selfesteem, trait anxiety, and authenticity metrics were used to the convergent validity. Reliability analyzes were conducted with internal consistency and two-week interval test-retest methods. As a result of the confirmatory factor analysis, the goodness of fit values was reached at the acceptable limits and the four-component structure of DSI-SF was verified. According to the results of the independent sample $t$ test and MANOVA on the difference of the 27\% upper and lower groups, scale scores differ significantly in the lower and higher levels of differentiation of self. Moreover, the results obtained from the correlation analyze show that the scale provides convergent validity. The Cronbach's alpha internal consistency coefficient was .82. Findings show that Differentiation of Self Inventory Short Form is a valid and reliable measurement tool.
\end{abstract}

\section{Benliğin Farklılaşması Envanteri Kısa Formunun (BFE-KF) Türkçe 'ye Uyarlanması: Geçerlik ve Güvenirlik Çalışması}

\begin{tabular}{|c|c|}
\hline \multicolumn{2}{|c|}{ Makale Bilgisi } \\
\hline \multicolumn{2}{|c|}{ DOI: 10.14686/buefad.364196 } \\
\hline \multicolumn{2}{|c|}{ Makale Geçmiși: } \\
\hline Geliş: & 09.12 .2017 \\
\hline Kabul: & 15.04 .2018 \\
\hline Yayın: & 30.06 .2018 \\
\hline \multicolumn{2}{|c|}{$\begin{array}{l}\text { Anahtar Kelimeler: } \\
\text { Benliğin farklılaşması, } \\
\text { Aile terapisi, } \\
\text { Ölçek uyarlama. }\end{array}$} \\
\hline $\begin{array}{l}\text { Makale } \\
\text { Arastırn }\end{array}$ & kalesi \\
\hline
\end{tabular}

\begin{abstract}
Öz
Bu çalışmanın amacı Benliğin Farklılaşması Envanteri Kısa Formunun Türkçe’ye uyarlanarak geçerlik ve güvenirlik analizlerinin gerçekleştirilmesidir. Araştırma grubu üniversite öğrencileri ve yetişkinlerden oluşan 20 - 64 yaş arası katılımcılardan oluşturulmuştur $(\bar{x}=30.69$, ss $=9.56)$. Ölçeğin yap1 geçerliği doğrulayıc1 faktör analizi ve \% 27'lik alt-üst grup arasındaki farkın manidarlığ geçerliğinin test edilmesinde benlik saygıs1, sürekli kaygı ve otantikliğe ilişkin ölçümlerden yararlanılmıştır. Güvenirlik analizleri ise iç tutarlık ve iki hafta süreli test tekrarı yöntemleriyle gerçekleştirilmiştir. Doğrulayıcı faktör analizi sonucunda kabul edilebilir sınırlarda uyum iyiliği değerlerine ulaşılmış ve BFE-KF'nin dört bileşenli yapısı doğrulanmıştır. Yüzde 27'lik alt-üst grup farkının manidarlığına ilişkin bağımsız örneklem $t$ testi ve MANOVA sonuçlarına göre, ölçek puanları benliğin farklılaşma düzeyi yüksek ve düşük gruplarda anlamlı şekilde farklılaşmaktadır. Ayrıca korelasyon analizlerinden elde edilen sonuçlar da ölçeğin uyum geçerliğini sağladığını göstermiştir. Cronbach alfa iç tutarlık katsayısı .82 olarak bulunmuştur. Bulgular, Benliğin Farklılaşması Envanteri Kısa Formunun geçerli ve güvenilir bir ölçme aracı olduğunu göstermektedir.
\end{abstract}

\footnotetext{
*Corresponding Author: yusufsarikaya@gmail.com

${ }^{a}$ Asst. Prof. Dr., Gaziosmanpaşa University, Tokat/Turkey. http://orcid.org/0000-0003-3057-3718

b Asst. Prof. Dr., İstanbul Medeniyet University, İstanbul/Turkey. http://orcid.org/0000-0001-6980-4857

${ }^{c}$ Assoc. Prof. Dr., Gaziosmanpaşa University, Tokat/Turkey. http://orcid.org/0000-0002-5007-5022

d Counselor, M.A., Şht. İbrahim Doğan Secondary School, Tokat/Turkey. http://orcid.org/0000-0001-5887-1050
} 


\section{Introduction}

Family therapies' assumption on that the family is decisive in the individual's behavior and self-development are now frequently used in psychological counseling and psychotherapy practice (Gladding, 2013). For this reason, family therapists emphasize that the client should be treated as a family member to better understanding or evaluation of their clients (Murdock, 2014). Murray Bowen's family systems theory is at the forefront of theories that emphasize the family in the development of the individual (Hainlen, Jankowski, Paine, \& Sandage, 2016; Murdock, 2014). Bowen $(1976,1985)$ has taken the 'differentiation of self' to the center of the theory of family systems that he developed. According to Bowen (1985), in the differentiation of self, the two dimensions come to the forefront in that the individual can take his own decisions without being influenced by others meaning a strong sense of self and individual's ability to separate his feelings and thoughts from each other.

The differentiation of the self does not have a negative meaning as the individual drift away from the society or family. In Bowen's theory (1985), it is defined as a process in which the individual does not break apart from the individual's family, but rather ends up with the family, without losing the sense of belonging to the individual's family (Bowen, 1985). In other words, the differentiation of self is the balance between individual's family ties and individuality. People with a high level of differentiation of self can stay calm and flexible in their social and interpersonal relationships; and those with low levels of differentiation of self are known to be emotionally drained and stressed (Lampis, Cataudella, Busonera, \& Skowron, 2017). Bowen who conceived the concept of differentiation of self $(1976,1985)$ tried to help his clients differentiate their selves in therapy practices and tried to measure the level of differentiation of self. Bowen (1978) defines self-differentiated individuals as people who can relate to other people without losing their self-perceptions, can transmit their feelings in a balanced way to the other individuals, and maintain their interpersonal relationships in a healthy manner. When the literature is examined, it is seen that the differentiation of self is related to many other variables such as family relationships (Ross, Hinshaw, \& Murdock, 2016), interpersonal relationships (Choi \& Murdock, 2017), depression (Drake, Murdock, Marszalek, \& Barber, 2015), anxiety (Xue et al., 2016), parental attachment problems (Hainlen et al., 2016), psychological symptoms (Krycak, Murdock, \& Marszalek, 2012), attachment problems (Lampis, Cataudella, et al., 2017; Ross et al., 2016), social anxiety (Peleg \& Zoabi, 2014), subjective well-being (Sandage $\&$ Jankowski, 2013). Therefore, learning the level of differentiation of self will provide important information to the field working specialists to evaluate the individual from different perspectives.

\section{Measuring the Differentiation of Self}

The multidimensional concept of differentiation of self is mainly based on two dimensions (Bowen, 1985). The first is the interpersonal dimension, in which the individual can distinguish himself emotionally and mentally from other people. Individuals with high levels of differentiation maintain their closeness to others while at the same time being independent of them (Hainlen et al., 2016). The second dimension of the differentiation of self is the intrapsychic dimension of the individual and includes the ability to distinguish the cognitive and emotional processes of the individual (Bowen, 1976, 1985). When examining early studies and scales measuring the differentiation of self, it is seen that a significant part of them are attempted to measure only certain dimensions of differentiation of self (Chabot, 1993; Kear, 1978; Licht \& Chabot, 2006; McCollum, 1991). In some other studies, it is seen that the multidimensional concept of differentiation of self is tried to be measured with uni-dimensional scales (Haber, 1993).

The first scale that measures the differentiation of self in a multidimensional manner is the Differentiation of Self Inventory-Revised (DSI-R) developed by Skowron and Friedlander (1998) and then revised by Skowron and Schmitt (2003). In this scale consisting of 46 items, the intrapsychic dimensions are called "I position" and "emotional reactivity". "I position" implies expressing the individual's emotions and thoughts in a responsible manner and encouraging the other individuals to express their own thoughts. In the emotional reactivity subscale, individualization is a matter of emotions suppressing thoughts, in other words suppression of the differentiation. The interpersonal dimensions of the relationship between the person and others are "fusion with others" and "emotional cutoff" dimensions. While in the emotional cutoff dimension, it is the case that individuals prefer to stay away from others and deny the importance of closeness, in the fusion with others dimension, distancing oneself from others is a threatening element (Bowen, 1976, 1985; Kerr and Bowen, 1988). DSI-R (Skowron \& Schmitt, 2003) has been used in many studies (Hainlen et al., 2016; Sandage, Jankowski, Bissonette, \& Paine, 2017; Skowron \& Dendy, 2004) and translated into many languages (Lamp and Chan-So, 2015, Lampis, Busonera, Cataudella, Tommasi, \& Skowron, 2017; Peleg, 2002). Drake et al. (2015), who think that too many items in the 
DSI-R (Skowron \& Schmitt, 2003) may be a problem for field experts or researchers who want to use the DSI-R, have developed a 20-item short form based on DSI-R. With the Differentiation of Self Inventory Short Form (DSI$\mathrm{SF}$ ), it is stated that voluntarily participation in researches on the subject can be increased and the field experts, who applied to the scale to clients during the counseling sessions, could save significant amount of time (Drake et al., 2015). Although recently developed, DSI-SF has been used in various studies (Choi \& Murdock, 2017; Ross et al., 2016; Sloan \& van Dierendonck, 2016).

The only study for measuring the differentiation of self conducted and can be reached in Turkey is the adaption of the 46-item DSI-R (Skowron Schmitt, 2003) to Turkish by Iş1k and Bulduk (2015). Although the psychometric properties of the DSI-R Turkish form are reported to be within acceptable limits in this study, it appears that the study has several problems, especially for the participant group. In this study, the study group formed to examine the construct validity contained the parents of the psychological counseling students (age range 42-65; $x^{-}=48.56$ ). In other words, single adults or young adult parents were not included in the study while adults who have children studying at the university was included. Yet Skowron and Friedlander (1998) have collected data from a wider age range (age range 25-65; $\mathrm{x}^{-}=36.80$ ) in the development stages of DSI-R. Similarly, Skowron and Schmitt (2003) collected data from a study group with the mean age of 36.31 ( $\mathrm{SD}=11.30$ ) (full age range not reported). It is thought that the Işık and Bulduk's choice of age range (2015) may be limited to some extent, considering the researches showing that there is a significant relation between the age and the level of differentiation of the self (e.g., Skowron \& Friedlander, 1998). In addition, while the original form of DSI-R consists of 46 items, the Turkish form consists of 20 items and 26 items are excluded from the scale. Therefore, this research is much like a new short form scale development study rather than an adaptation study. For this reason, it would be useful to work on a new adaptation to measure the level of differentiation of self. Thus, it has been decided to adapt DSI-SF (Drake et al., 2015) to Turkish, which provides shorter measurements in this study.

\section{Method}

\section{Data Collection Tools}

In this study, Rosenberg Self-Esteem Scale (Rosenberg, 1965), The State-Trait Anxiety Inventory (Spielberger, Gorsuch, \& Lushene, 1970) and the Authenticity Scale (Wood, Linley, Maltby, Baliousis, \& Joseph, 2008) were used in addition to DSI-SF (Drake et al., 2015) Turkish form as data collection tool. Demographic data related to the research group were collected through personal information form. Information on the scales used as data collection tools are presented below.

The Differentiation of Self Inventory Short Form (DSI-SF). DSI-SF, which offers more short-term measurements for differentiation of self, has been developed by Drake et al. (2015) based on a 46-item DSI-R. DSI-SF consists of 20 items that are divided into four subscales. To rate each item, respondents used a 6-point Likert-type scale, ranging from not at all true of me (1) to very true of me. While 'emotional reactivity', 'emotional cutoff', and 'fusion with others' dimensions are reversely scored, only one item is scored reversely in the 'I position' dimension. Thus, high scores from the reverse scored dimensions mean that no behavior or situations are observed for that dimension. More precisely, for example, high scores from emotional cutoff mean low levels of emotional cutoff. On the contrary, the high scores from the I position dimension indicate that the individual has a higher level of having I position. Thus, high scores from each of the subscales contribute to different dimensions of the level of differentiation of self, indicating a high level of differentiation of the self. The subscale scores are calculated by taking the averages according to the number of items in that subscale. Similarly, the average of the four subscale scores gives the total scale score. While the Cronbach's alpha internal consistency coefficients for emotional reactivity, emotional cutoff, fusion with others and I position dimensions and scale total scores were found to be $.80, .79, .68, .70$ and .88 , respectively; The five-week interval test-retest reliability coefficients were found to be $.82, .81, .72, .74$ and .85 (Drake et al., 2015).

Rosenberg Self-Esteem Scale (RSES). The scale developed by Rosenberg (1965) has a total of 10 items. The Turkish adaptation study of the scale was carried out by Çuhadaroğlu (1986). In this study, the 4-week test-retest reliability of RSES was found as .75. The validity of the scale was examined through a correlation between interviews with the psychiatric sample and scale scores found to be .71. High scores from the scale indicate high self-esteem.

The Authenticity Scale (AS). The scale developed by Wood et al. (2008) consists of 12 items and 3 subscales. The Turkish adaptation study of the scale was carried out by Ilhan and Özdemir (2013). In this study, Cronbach's 
alpha internal consistency coefficients for self-alienation, accepting external influence and authentic living subscales were found to be $.79, .67, .62$, respectively. In addition, while there were negative relationships between self-alienation, accepting external influences, self-esteem and life satisfaction, positive relationships were found between authentic living, self-esteem and life satisfaction. The fact that the authentic living subscale score is high, and the scores of other dimensions are low suggests that the individual is authentic. The Cronbach's alpha reliability coefficient for the subscales of the scale was found to be $.77, .79$ and .64 , respectively in this study.

The State-Trait Anxiety Inventory (STAI). The scale developed by Spielberger et al. (1970) to measure the trait anxiety levels of individuals consists of 20 items. The Turkish adaptation study of the scale was conducted by Öner and Le Compte (1983) and the Cronbach's alpha reliability coefficient was reported as .72. High scores from the scale indicate high level of chronic concern. The Cronbach's alpha reliability coefficient of the scale was found to be .84 in this study.

\section{Participants}

Participants consisted of 447 university students and adult population. A total of 225 university students are volunteers to attend the different faculties and departments of the two state universities with ages ranged from 20 to $64(\bar{x}=30.69$, sd $=9.56)$. In terms of other demographic variables, $265(59.28 \%)$ of were women and 182 $(40.72 \%) 250(55.93 \%)$, single, 189 (42.28\%), married, and 8 (1.79\%) divorced. The test-retest reliability of DSISF was examined by a different participant consisting of 57 university students. The age of the participants ranged from 20 to $24(\bar{x}=21.58$, sd $=.80)$; 39 of them were women $(68.42 \%)$ and 18 men $(31.58 \%)$. Only two of the participant in this group were married $(3.51 \%)$ while the others were single $(96.49 \%)$.

\section{Procedure}

After permission for the adaptation of the DSI-SF (Drake et al., 2015) were obtained from the researchers, the scale items were translated to Turkish. Then, items were assessed in terms of grammar and understandability by a Turkish language expert. The final DSI-SF Turkish form was shaped in accordance with the expert opinions. In the process of data collection, the purpose of study was explained to the participants and the application was performed with the volunteers. The scale applications took approximately 20 minutes. While the applications of the university students are conducted in the classroom environment, the applications of adults are carried out in various environments outside the classroom (i.e., workplace).

\section{Data Analysis}

The construct validity of the Turkish adaptation of the DSI-SF (Drake et al., 2015) was examined by confirmatory factor analysis with maximum likelihood estimation method. In the confirmatory factor analysis, $\chi 2$, $\chi 2$ / sd statistics, the goodness of fit indexes, error variances and $t$ values of the items, were examined. The goodness of fit indexes was evaluated based on the criteria RMSEA <.10 (Bentler \& Bonett, 1980), CFI $\geq .90$ (Bentler, 1990), IFI $\geq .90$ (Bollen, 1989), NFI $\geq .80$ (Marsh, Balla, \& McDonald, 1988; Bentler \& Bonett, 1980), NNFI $\geq .90$ (Bentler \& Bonett, 1980), GFI $\geq .85$ (Jöreskog \& Sörbom, 1988), AGFI $\geq .80$ (Marsh et al., 1988), and SRMR $\leq$ .08 (Brown, 2006; Hu \& Bentler, 1999). In addition, whether the DSI-SF Turkish form performs distinctive measures was examined by the significance of the $27 \%$ upper and lower group difference.

The RBSE and the STAI, which were also used in developmental processes of the original form of DSI-SF (Drake et al., 2015; Skowron \& Friedlander, 1998), were preferred for investigation the convergent validity of the Turkish form of DSI-SF. Unlike other studies, in this study, measures of authenticity, which revealed to have a similar structure to the differentiation of self (Wood et al., 2008), were also utilized. Thus, correlations between the scores of the three scales applied to examine the convergent validity and the scores of the DSI-SF Turkish form were calculated. The reliability of the DSI-SF Turkish form was investigated using the Cronbach's alpha internal consistency coefficient and two-week interval test-retest methods. 


\section{Findings}

\section{Construct Validity}

In the context of the validity study, the four-component structure of the original form of BFE-KF (Drake et al., 2015) was tested by confirmatory factor analysis using the maximum likelihood method. In the confirmatory factor analysis, firstly the $t$ values related to the scale items were examined and it was seen that all of the values were significant. In addition, the error variances of the items were examined, and it was seen that there was no problem in this respect. As a result of analysis, $\chi 2{ }_{(163)}=558.98,(p<.001), \chi^{2} / s d=3.43$, RMSEA $=.07$, CFI $=.91$, IFI $=$ $.91, \mathrm{NFI}=.88, \mathrm{NNFI}=.90, \mathrm{GFI}=.89, \mathrm{AGFI}=.86$; $\mathrm{SRMR}=.07$ were found. The values obtained from the results of confirmatory factor analysis were interpreted as a confirmation of the four-component structure in Turkish form like in the original form of DSI-SF.

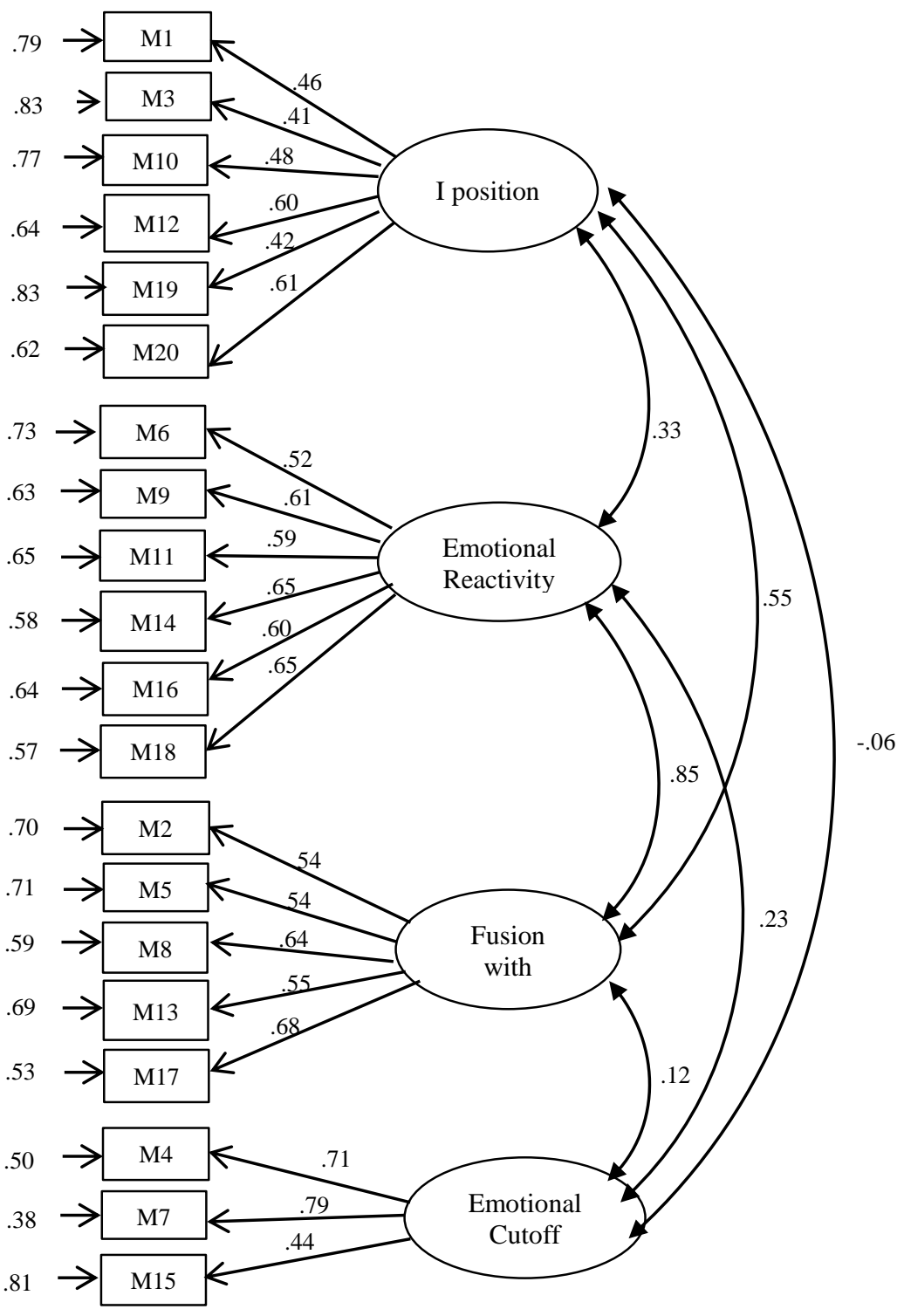

Figure 1. Four-Component Structure of the Turkish Form of the DSI-SF 
The analysis findings showed that all the loadings of items were positive and significant. The loadings of the items range from .41 to .79. The lowest loading belongs to the " No matter what happens in my life, I know that I'll never lose my sense of who I am." item (item 3), which is in the I position subscale. The highest loading belongs to the item of "I'm often uncomfortable when people get too close to me." (item 7), which is in the dimension of emotional cutoff. A four-component structure of the DSI-SF Turkish form is given in Figure 1.

Significance of the Difference between upper and lower 27\%. It has been tested whether the DSI-SF Turkish form makes distinctive measurements to provide evidence for the construct validity. For this purpose, the significance of $27 \%$ upper and lower group difference was examined by independent sample $t$ test and multivariate analysis of variance (MANOVA). Firstly, considering the scale total scores, two groups with higher $(\mathrm{n}=121)$ and lower $(n=121)$ levels of differentiation of self were determined. Then, it was examined whether the mean of the DSI-SF total score and subscale scores significantly differed in the upper and lower groups. The Levene F test showed that the variances were equally distributed in the DSI-SF total score and subscale scores ( $p>.05)$. Variances were not found to be equal in only the fusion with others subscale ( $<$ <.05). Independent sample $t$ test results showed that the DSI-SF total scores significantly differed from the upper $[\bar{x}=4.90(\mathrm{sd}=.32)]$ and the lower $[x=3.08(\mathrm{sd}=.39)]$ groups $\left[\mathrm{t}_{(240)}=40.06\right]$. Whether the subscale scores differ significantly in the upper and lower groups was tested with MANOVA. MANOVA revealed that subscale scores differed significantly in the higher and lower groups [Wilks' Lambda $=.13$, Pillai's Trace $=.87, \mathrm{~F}_{(4,237)}=401.33, \mathrm{p}<.001, \eta 2=.87$ ]. ANOVA findings also showed that emotional cutoff $\left[F_{(1,240)}=60.28, \mathrm{p}<.001, \eta^{2}=.20\right]$, emotional reactivity $\left[F_{(1,240)}=\right.$ $\left.777.96, \mathrm{p}<.001, \eta^{2}=.76\right]$, I position $\left[F_{(1,240)}=186.76, \mathrm{p}<.001, \eta^{2}=.44\right]$, and fusion with others $\left[F_{(1,240)}=661.85\right.$, $\mathrm{p}<.001, \eta^{2}=.73$ ] subscale scores significantly differed in the upper and lower groups.

\section{Convergent Validity}

DeVellis (2012) stated that any construct assures convergent validity if it is related to other constructs that are theoretically expected to be related. In order to evaluate the convergent validity, the relationships between the scores of the Turkish form of DSI-SF, trait anxiety, self-esteem, accepting external influences, self-alienation and authentic living were examined. Significant correlations were found between scores of the Turkish form of DSI$\mathrm{SF}$ and other relevant constructs. Correlation coefficients are given in Table 1.

Table 1. Means, Standard Deviations, Correlations, Convergent Validity and Reliability Coefficients of the Total and Subscale Scores of the Turkish form of the DSI-SF

\begin{tabular}{|c|c|c|c|c|c|}
\hline & \multicolumn{5}{|c|}{ Turkish form of DSI-SF } \\
\hline & $\begin{array}{c}\text { Emotional } \\
\text { Reactivity } \\
\text { Subscale } \\
{[n=6]}\end{array}$ & $\begin{array}{c}\text { Emotional } \\
\text { Cutoff } \\
\text { Subscale } \\
{[n=3]}\end{array}$ & $\begin{array}{c}\text { Fusion } \\
\text { with } \\
\text { Others } \\
\text { Subscale } \\
{[n=5]}\end{array}$ & $\begin{array}{c}\text { I position } \\
\text { Subscale } \\
{[n=6]}\end{array}$ & $\begin{array}{c}\text { Turkish } \\
\text { Form of } \\
\text { DSI-SF } \\
\text { (Total) } \\
{[n=20]}\end{array}$ \\
\hline Trait Anxiety Inventory & $-.57 * *$ & -.07 & $-.55 * *$ & $-.41 * *$ & $-.62 * *$ \\
\hline Rosenberg Self-Esteem Scale & $.24 * *$ & .06 & $.29 * *$ & $.36 * *$ & $.35 * *$ \\
\hline \multicolumn{6}{|l|}{ Authenticity Scale } \\
\hline Accepting External Influence & $-.48 * *$ & -.03 & $-.63 * *$ & $-.43 * *$ & $-.60 * *$ \\
\hline Self-Alienation & $-.31 * *$ & $-.18 * *$ & $-.50 * *$ & $-.43 * *$ & $-.52 * *$ \\
\hline Authentic Living & $-.11 *$ & $.10 *$ & $.11 *$ & $.30 * *$ & $.12 *$ \\
\hline Cronbach $\alpha$ Coefficients & .78 & .66 & .72 & .61 & .82 \\
\hline Test-retest Coefficients & $.80 * *$ & $.73 * *$ & $.70 * *$ & $.73 * *$ & $.86 * *$ \\
\hline Means & 3.31 & 4.04 & 4.19 & 4.49 & 4.01 \\
\hline Standard Deviations & 1.12 & 1.19 & 1.09 & .85 & .73 \\
\hline
\end{tabular}

$* * p<.01 * *<<.05$

\section{Reliability}

Internal consistency and test-retest reliability analyzes were performed regarding the Turkish form of DSI-SF total score and subscale scores. The Cronbach's alpha internal consistency reliability coefficient for the DSI-SF total score was .83. Internal consistency reliability coefficients for subscales ranged between .61 (I position subscale) and .78 (emotional reactivity subscale). The two-week interval test-retest reliability coefficients were 
.86 for the DSI-SF total score, and for the subscales they range from .80 (emotional reactivity subscale) to .70 (fusion with others subscale). The reliability values of DSI-SF are given in Table 1.

\section{Discussion and Conclusion}

The analyzes carried out to examine the construct validity of the Turkish form of the DSI-SF showed that the four-component structure of the original form is also confirmed in the Turkish form. The $\chi^{2} /$ sd value for confirmatory factor analysis meets the suggested criterion in the literature (MacCallum, Brown, \& Sugawara, 1996). Similarly, goodness of fit indices appears to be within acceptable limits (Bentler, 1990, Bentler \& Bonett, 1980, Bollen, 1989, Marsh et al., 1988). The results of the independent sample $t$ test and MANOVA conducted to measure the difference between the upper and lower $27 \%$ of the groups reveal that the DSI-SF total score and subscale scores differ significantly in the higher and lower levels of differentiation of self. All these findings indicate that the Turkish form of the DSI-SF is valid.

Findings related to the convergent validity indicate that there is negative and significant relationship between the level of differentiation of self and trait anxiety. Similarly, Xue et al. (2016) found that there is a negative relationship between the differentiation of self and anxiety, social phobia, and panic disorders. Peleg and Zoabi (2014) also say that there is a negative relationship between social anxiety and differentiation of self. In this study, positively significant relationships were detected between the level of differentiation of self and self-esteem. These findings support the results of previous research (Drake et al., 2015; Skowron and Friedlander, 1998). However, it is seen that the emotional cutoff subscale did not show a significant relationship with the trait anxiety and selfesteem. When the literature is examined, there is some inconsistent findings related to the emotional cutoff. For instance, in the study of Favre, Reynaud and Caussidier (2012), it is reported that there isn't a significant relationship between emotional cutoff and self-esteem while in the studies of Skowron and Friedlander (1998) and Işık and Bulduk (2014) a significant relationship between emotional cutoff and self-esteem was found. Individuals with emotional cutoff tend to be more distant from others and deny the importance of closeness. Perhaps these individuals may tend to show a high level of self-esteem to protect themselves. Although the relationship between avoidant attachment and emotional cutoff has not been investigated in this study, positive relationships between avoidant attachment and emotional cutoff have been reported in the literature (Wei, Vogel, Ku, \& Zakalik, 2005). From this finding, it can be said that individuals who experience emotional cutoff may tend to appear stronger and suppress their worries when they break their emotional ties with others. To test the accuracy of these proposed opinions, the mediating role of attachment styles between emotional cutoff and self-esteem can be examined in the future. A similar situation is seen in the relationships between the scores of the differentiation of self and the authenticity subscales. Negative significant relationships exist between the differentiation of self and selfalienation and accepting external influences. Relations between emotional cutoff subscale scores and authenticity dimensions are limited.

In general, the reliability coefficients of psychological measuring instruments are estimated to be .70 and above as proof of the reliability of the instrument (DeVellis, 2012; Nunnally \& Bernstein, 1994). The Cronbach's alpha reliability coefficient for the Turkish form of the DSI-SF total score meets the recommended criterion value in the literature. Internal consistency coefficients of DSI-SF subscales vary between .61 and .78. The two-week interval test-retest reliability values also meet the recommended value. This indicates that DSI-SF make stable measurements.

In conclusion, the findings of the validity and reliability analyzes show that DSI-SF is a valid and reliable measurement tool. This study was conducted with a non-clinical research group. The four-component structure of Turkish form of the DSI-SF can be tested with different groups of clients in future studies. Using Turkish form of the DSI-SF, the researchers could investigate relationships between differentiation of self and other psychological constructs (i.e. depression, hopelessness) except attachment styles, self-esteem and anxiety. Thus, more detailed explanations can be made to conceptualize the differentiation of self in Turkish culture.

\section{Acknowledgment}

Preliminary version of this paper has been presented at the 2nd Eurasian Congress on Positive Psychology at Üsküdar University, in Istanbul, Turkey. This study was supported by Tokat Gaziosmanpaşa University Scientific Research Projects Unit. Project number: 2017/33. 


\section{Benliğin Farklılaşması Envanteri Kısa Formunun (BFE-KF) Türkçe 'ye Uyarlanması: Geçerlik ve Güvenirlik Çalışması}

\section{Giriş}

Ailenin bireyin davranışlarında ve benlik gelişiminde belirleyici olduğu varsayımından yola çıkan aile terapileri, günümüzde psikolojik danışmada ve psikoterapi uygulamalarında sıklıkla kullanılmaktadır (Gladding, 2013). Bu nedenle, aile terapistleri danışanlarını daha iyi anlamak ya da değerlendirmek için danışanın bir aile üyesi olarak ele alınması gerektiğini vurgulamaktadırlar (Murdock, 2014). Bireyin benlik gelişiminde aileye vurgu yapan kuramların başında Murray Bowen'nın aile sistemleri kuramı gelmektedir (Hainlen, Jankowski, Paine, \& Sandage, 2016; Murdock, 2014). Bowen $(1976,1985)$ geliştirmiş olduğu aile sistemleri kuramının merkezine benliğin farklılaşmasını (differentation of self) almıştır. Bowen'a (1985) göre benliğin farklılaşmasında, bireyin başkalarının etkisinde kalmadan kendi kararlarını alabilmesi yani güçlü bir benlik duygusuna sahip olması ve bireyin duygularıyla düşüncelerini birbirinden ayırması olmak üzere iki boyut ön plana çımaktadır.

Benliğin farklılaşması bireyin toplumdan ya da ailesinden uzaklaşması gibi olumsuz bir anlam içermemektedir. Bowen'ın (1985) kuramında, benliğin farklılaşmasıyla anlatılmak istenen bireyin ailesinden kopması değil, aksine bireyin ailesine aidiyet duygusunu kaybetmeden, ailesiyle birliktelik içinde tamamladığ 1 bir süreç olarak tanımlanmaktadır (Bowen, 1985). Başka bir anlatımla benliğin farklılaşması bireyin aile bağlarıyla bireyselliği arasında bir denge oluşturmasıdır. Benliği farklılaşma düzeyi yüksek olan kişilerin, toplumsal ve kişilerarası ilişkilerinde sakin kalabildikleri ve esnek davranabildikleri; farklılaşma düzeyi düşük kişilerin ise duygularla boğulmuş ve stres düzeyi yüksek kişiler olduğu bilinmektedir (Lampis, Cataudella, Busonera, \& Skowron, 2017). Benliğin farklılaşması kavramını alanyazına kazandıran Bowen (1976, 1985), terapi uygulamalarında, danışanlarının benliklerini farklılaştırmalarına yardımcı olmaya çalışmış ve benliğin farklılaşma düzeyini ölçmeye çalışıışır. Bowen (1978) benliği farklılaşmış bireyleri, kendi benlik algılarını yitirmeden diğer insanlarla ilişki kurabilen, duygularını dengeli bir biçimde karşıdaki bireylere ileten ve kişilerarası ilişkilerini sağlıklı bir biçimde sürdürebilen kişiler olarak tanımlamıştır. Alanyazın incelendiğinde benliğin farklılaşmasının, aile ilişkileri (Ross, Hinshaw, \& Murdock, 2016), kişilerarası ilişkiler (Choi \& Murdock, 2017), depresyon (Drake, Murdock, Marszalek, \& Barber, 2015), kaygı (Xue ve diğerleri, 2016), ebeveyn bağlanma problemleri (Hainlen ve diğerleri, 2016), psikolojik belirtiler (Krycak, Murdock, \& Marszalek, 2012), bağlanma sorunları (Lampis, Cataudella, \& diğerleri, 2017; Ross ve diğerleri, 2016), sosyal kayg1 (Peleg \& Zoabi, 2014), manevi iyilik hali (Sandage \& Jankowski, 2013) gibi farklı birçok değişkenle ilişkili oluğu görülmektedir. Dolayısıyla benliğin farklılaşma düzeyini öğrenmek bireyi farklı açılardan değerlendirebilmek adına alanda çalışan uzmanlara önemli bir bilgi sunacaktır.

\section{Benliğin Farklılaşmasının Ölçülmesi}

Çok boyutlu bir kavram olan benliğin farklılaşması, temel olarak iki boyutundan oluşmaktadır (Bowen, 1985). Bunlardan ilki bireyin duygu ve düşünce olarak kendisini diğer insanlardan ayırt edebilmesini içeren kişilerarası (interpersonal) boyuttur. Farklılaşma düzeyi yüksek olan bireyler diğerleriyle yakınlığını korurken, aynı zamanda onlardan bağımsızlaşabilmektedirler (Hainlen ve diğerleri, 2016). Benliğin farklılaşmasının ikinci boyutu ise bireyin iç dünyası ile ilgili (intrapsychic) boyuttur ve bireyin bilişsel ve duygusal süreçlerini birbirinden ayırabilmesini içermektedir (Bowen, 1976; 1985). Benliğin farklılaşmasının ölçülmesine yönelik erken dönem çalışmalar ve geliştirilen ölçekler incelendiğinde, bunların önemli bir kısmında benliğin farklılaşmasının yalnızca belirli boyutlarının ölçülmeye çalışıldığı görülmektedir (Chabot, 1993; Kear, 1978; Licht \& Chabot, 2006; McCollum, 1991). Diğer bazı çalışmalarda ise çok boyutlu bir kavram olan benliğin farklılaşmasının tek boyutlu ölçeklerle ölçülmeye çalışıldığı görülmektedir (Haber, 1993).

Benliğin farklılaşmasını çok boyutlu bir şekilde ölçen ilk ölçek Skowron ve Friedlander (1998) tarafindan geliş̧irilen ve daha sonra Skowron ve Schmitt (2003) tarafından gözden geçirilen benliğin farklılaşması envanteri revize formudur (BFE-R). Toplam 46 maddeden oluşan bu ölçekte bireyin kendi iç yaşantısına yönelik (intrapsychic) alt boyutlar "ben pozisyonu alma" ve "duygusal tepkisellik" olarak adlandırılmışıır. Ben pozisyonu alma, bireyin duygu ve düşüncelerini sorumlu bir biçimde ifade etmesini ve diğer bireyleri de kendi düşüncelerini ifade etme konusunda cesaretlendirmesini içermektedir. Duygusal tepkisellik alt boyutunda ise duyguların düşünceleri bastırması nedeni ile bireyselleşmenin, diğer bir ifade ile farklılaşmanın bastırılması söz konusudur. Kişinin başkalarıyla olan ilişkisine yönelik alt boyutlar (interpersonal) ise "iç içe geçme" ve "duygusal kopma" boyutlarıdır. Duygusal kopma boyutunda bireylerin diğerlerinden uzak durmaları, yakınlı̆ı̆ı önemini inkar etmeleri söz konusuyken, iç içe geçme boyutunda diğerlerinden uzak kalma tehdit edici bir unsur olarak görülür (Bowen, 1976, 1985; Kerr ve Bowen, 1988). BFE-R (Skowron \& Schmitt, 2003) pek çok çalışmada kullanılmış (Hainlen ve diğerleri, 2016; Sandage, Jankowski, Bissonette, \& Paine, 2017; Skowron \& Dendy, 2004) ve birçok dile çevrilmiştir (Iş̧1k ve Bulduk, 2015; Lam \& Chan-So, 2015; Lampis, Busonera, Cataudella, Tommasi, \& Skowron, 2017; Peleg, 2002). BFE-R'deki (Skowron \& Schmitt, 2003) madde sayısının fazla oluşunun ölçeği 
kullanmak isteyen alan uzmanları ya da araştırmacılar için sorun oluşturabileceğini düşünen Drake ve diğerleri (2015) BFE-R'ye dayalı 20 maddeli bir kısa form geliştirmişlerdir. Benliğin farklılaşması envanteri kısa formuyla (BFE-KF) konu ile ilgili gerçekleştirilecek araştırmalara gönüllü katılımın artırılabileceğini, danışma sırasında ölçeği danışanlarına uygulayan alan uzmanlarının ise zamandan önemli oranda tasarruf edebileceklerini belirtmişlerdir (Drake ve diğerleri, 2015). BFE-KF yakın zamanda geliştirilmiş olmasına rağmen çeşitli araştırmalarda kullanılmıştır (Choi \& Murdock, 2017; Ross ve diğerleri, 2016; Sloan \& van Dierendonck 2016).

Benliğin farklılaşmasının ölçümüne yönelik Türkiye'de gerçekleştirilen ve ulaşılabilen tek çalışma Işık ve Bulduk (2015) tarafından gerçekleştirilen, 46 maddeli BFE-R'nin (Skowron Schmitt, 2003) Türkçe'ye uyarlanmasına yönelik araştırmadır. Bu çalışmada BFE-R Türkçe formunun psikometrik özelliklerinin kabul edilebilir sınırlarda olduğu rapor edilmekle birlikte, araştırmanın özellikle katılımcı grup yönüyle çeşitli sorunlar barındırdığı görülmektedir. Bu araştırmada yapı geçerliğin incelendiği araştırma grubunu psikolojik danışmanlık öğrencilerinin ebeveynleri oluşturmuştur (yaş aralığı 42-65; $\bar{x}=48.56$ ). Başka bir ifadeyle araştırmaya çocuğu üniversite okuyan yetişkinler dâhil edilirken, bekar yetişkinler ya da genç yetişkin ebeveynler dahil edilmemiştir. Oysaki BFE-R'nin geliştirme aşamalarında Skowron ve Friedlander (1998) daha geniş bir yaş aralığından veri toplamışlardır (yaş aralığı 25-65; $\bar{x}=36.80$ ). Benzer şekilde, Skowron ve Schmitt (2003) ise yaş ortalaması 36.31 olan $(s d=11.30)$ bir araştırma grubundan veri toplamışlardır (tam yaş aralığı raporlanmamıştır). Yaş ile benliğin farklılaşma düzeyleri arasından anlamlı ilişkiler olduğu gösteren araştırmalar dikkate alındığında (Ör., Skowron \& Friedlander, 1998), Işık ve Bulduk'un (2015) seçtikleri yaş aralığının kapsam açısından sınırlı kalabileceği düşünülmüştür. Ayrıca BFE-R'nin orijinal formu 46 maddeden oluşurken, Türkçe formu 20 maddeden oluşmuş, 26 madde ölçek dışında bırakılmıştır. Bu haliyle araştırma, bir uyarlama çalışmasından çok yeni bir kısa form ölçek geliştirme çalışmasına benzemektedir. Bu nedenle benliğin farklılaşması düzeyinin ölçümüne yönelik yeni bir uyarlama çalışmasının yararlı olacağı değerlendirilmiştir. Böylece bu araştırmada daha kısa ölçümler sunan BFE-KF'nin (Drake ve diğerleri, 2015) Türkçe' ye uyarlanmasına karar verilmiştir.

\section{Yöntem}

\section{Veri toplama araçları}

$\mathrm{Bu}$ araştırmada veri toplama aracı olarak BFE-KF (Drake ve diğerleri, 2015) Türkçe formunun yanı sıra Rosenberg Benlik Saygısı Envanteri (Rosenberg, 1965), Sürekli Kaygı Ölçeği (Spielberger, Gorsuch, \& Lushene, 1970) ve Otantiklik Ölçeği (Wood, Linley, Maltby, Baliousis, \& Joseph, 2008) kullanılmıştır. Araştırma grubuna ilişkin demografik veriler ise kişisel bilgi formu ile toplanmıştır. Veri toplama aracı olarak kullanılan ölçeklere ilişkin bilgiler aşağıda sunulmuştur.

Benliğin Farklılaşması Envanteri-Kısa Form (BFE-KF). Benliğin farklılaşmasına ilişkin daha kısa süreli ölçümler yapma imkanı sunan BFE-KF, 46 maddeli BFE-R'ye dayalı olarak Drake ve diğerleri (2015) tarafından geliştirilmiştir. BFE-KF, 20 maddeli ve dört alt boyuttan oluşmaktadır. Altılı Likert tipinde olan maddeler 1 (Beni hiç yansıtmıyor) ile 6 (Beni oldukça yansıtıyor) arasında puanlanmaktadır Duygusal tepkisellik, duygusal kopma ve iç içe geçme boyutları tersine puanlanan maddelerden oluşurken, ben pozisyonu alma boyutunda yalnızca bir madde tersine puanlanmaktadır. Böylece tersine puanlanan boyutlardan alınan yüksek puanlar o boyutla ilgili davranış ya da durumların gözlenmediği anlamına gelmektedir. Daha açık bir ifadeyle, örneğin duygusal kopma boyutundan alınan yüksek puanlar duygusal kopma düzeyinin düşük olduğu anlamına gelmektedir. Bunun tersine, ben pozisyonu boyutundan alınan yüksek puanlar ise bireyin ben pozisyonu alma düzeyinin yüksekliğini göstermektedir. Böylece alt ölçeklerin her birinden alınan yüksek puanlar benliğin farklılaşma düzeyinin farklı boyutlarına katkı sağlamakta ve benliğin farklılaşma düzeyinin yüksekliğine işaret etmektedir. . Alt ölçek puanları o alt ölçekteki madde sayısına göre ortalamaların alınmasıyla hesaplanmaktadır. Benzer şekilde, dört alt ölçek puanının ortalaması ise ölçek toplam puanını vermektedir. Duygusal tepkisellik, duygusal kopma, iç içe geçme ve ben pozisyonu boyutları ile ölçek toplam puanına ilişkin Cronbach alfa iç tutarlık katsayıları sırasıyla .80, .79, .68, .70 ve .88 olarak bulunurken, beş hafta süreli test-tekrar test güvenirlik katsayıları ise $.82, .81, .72, .74$ ve .85 olarak bulunmuştur (Drake ve diğerleri, 2015).

Rosenberg Benlik Saygısı Ölçeği (RBSÖ). Rosenberg (1965) tarafindan geliştirilen ölçek toplam 10 maddeden oluşmaktadır. Ölçeğin Türkçe uyarlama çalışması Çuhadaroğlu (1986) tarafından gerçekleştirilmiştir. Bu çalışmada RBSÖ’nün 4 hafta süreli test-tekrar test güvenirliği 75 bulunmuştur. Ölçeğin geçerliği ise psikiyatri örneklemi ile yapılan görüşmeler ile ölçek puanları arasındaki korelasyon yoluyla incelenmiş ve .71 olarak bulunmuştur. Ölçekten alınan yüksek puanlar benlik saygısının yüksekliğine işaret etmektedir. 
Otantiklik ölçeği (Ö̈). Wood ve diğerleri (2008) geliştirilen ölçek 12 madde ve 3 alt boyuttan oluşmaktadır. Ölçeğin Türkçe uyarlama çalışması İlhan ve Özdemir (2013) tarafindan gerçekleştirilmiştir. Bu çalışmada ölçeğin alt boyutları olan kendine yabancılaşma, dış etkileri kabullenme ve otantik yaşam için Cronbach alfa iç tutarlılık katsayıları sırasıyla $.79, .67, .62$ olarak bulunmuştur. Ayrıca, kendine yabancılaşma ve dış etkileri kabullenme ile arasında olumsuz yönde ilişkiler bulunurken, otantik yaşam ile benlik saygısı ve yaşam doyumu arasında olumlu yönde ilişkiler bulunmuştur. Otantik yaşam alt boyutu puanının yüksek, diğer boyutlara ait puanlarının düşük olması o bireyin otantik olduğunu işaret etmektedir. Ölçeğin alt boyutlarına ilişkin Cronbach alfa güvenirlik katsayısı bu çalışmada sırasıyla $.77, .79$ ve .64 olarak bulunmuştur.

Sürekli kaygı envanteri (SKE). Bireylerin sürekli (kronik) kaygı seviyelerini ölçmek amacıyla Spielberger ve diğerleri (1970) tarafindan geliştirilen ölçek 20 maddeden oluşmaktadır. Ölçeğin Türkçe uyarlama çalışması Öner ve Le Compte (1983) tarafindan yapılmış ve Cronbach alfa güvenirlik katsayısı.72 olarak rapor edilmiştir. Ölçekten alınan yüksek puanlar yüksek düzey sürekli kaygıya işaret etmektedir. Ölçeğin Cronbach alfa güvenirlik katsayısı bu çalışmada ise .84 olarak bulunmuştur.

\section{Katılımeılar}

BFE-KF'nin Türkçe uyarlama çalışması üniversite öğrencileri ile yetişkinlerden oluşan toplam 447 kişilik bir katılımcı grubuyla gerçekleștirilmiş̧ir. Katılımcıların \% 50.34'ü üniversite öğrencisi, \% 49.66'sı yetişkindir. Katılımcılarının 265'i (\% 59.28) kadınlardan, 182'si erkeklerden (\% 40.72) oluşurken; 250'si bekâr (\% 55.93), 189'u evli (\% 42.28) ve 8'i (\% 1.79) boşanmış bireylerden oluşmaktadır. BFE-KF'nin test tekrarı güvenirliği üniversite öğrencilerinden oluşan 57 kişilik bir katılımcı grubuyla incelenmiştir. Öğrencilerin yaşları 20 ile 24 arasında değişirken $(\bar{x}=21.58$, ss $=.80)$; 39'u kadın (\% 68.42), 18'i erkeklerden (\% 31.58) oluşmaktadır. $\mathrm{Bu}$ grupta yer alan öğrencilerden yalnızca ikisi evliyken (\% 3.51), diğerleri bekardır (\% 96.49).

\section{İşlem}

Öncelikle, BFE-KF'nin (Drake ve diğerleri, 2015) Türkçe'ye uyarlanması amacıyla araştırmacılardan izin alınmıştır. Uyarlama sürecine ölçek maddelerinin çevirileri ile başlanmıştır. Daha sonra, ölçek maddeleri bir Türk Dili uzmanı tarafından dilbilgisi ve anlaşılırlık açısından kontrol edilmiştir ve BFE-KF Türkçe formuna son şekli verilmiştir. Veri toplama sürecinde öncelikle katılımcılara çalışmanın amacı açıklanımış ve gönüllü olanlarla uygulama yapılmıştır. Ölçek uygulamaları yaklaşık 20 dakika sürmüştür. Üniversite öğrencilerinin uygulamaları sınıf ortamında yapılırken, yetişkinlerin uygulamaları sınıf dışındaki çeşitli ortamlarda (Ör., çalışma yerleri) yapılmıştır.

\section{Verilerin Analizi}

BFE-KF (Drake ve diğerleri, 2015) Türkçe formunun yapı geçerliliği en çok olabilirlik yöntemi (maximum likelihood) ile gerçekleştirilen doğrulayıc faktör analizi ile incelenmiştir. Doğrulayıcı faktör analizinde $\chi^{2}, \chi 2 / s d$ istatistikleri ve uyum iyiliği indeksleri ile ölçek maddelerine ilişkin hata varyansları ve $t$ değerleri incelenmiştir. Uyum iyiliği indekslerinin değerlendirilmesinde RMSEA <.10 (Bentler \& Bonett, 1980), CFI $\geq .90$ (Bentler, 1990), IFI $\geq .90$ (Bollen, 1989), NFI $\geq .80$ (Marsh, Balla, \& McDonald, 1988; Bentler \& Bonett, 1980), NNFI $\geq .90$ (Bentler \& Bonett, 1980), GFI $\geq .85$ (Jöreskog \& Sörbom, 1988), AGFI $\geq .80$ (Marsh ve diğerleri, 1988), SRMR $\leq .08$ (Brown, 2006; Hu \& Bentler, 1999) kriterleri esas alınmıştır. Ayrıca BFE-KF Türkçe formunun ayırt edici ölçümler yapıp yapmadığı \% 27'lik alt-üst grup farkının manidarlığını ile incelenmiş̧ir.

BFE-KF Türkçe formunun uyum geçerliğini incelemek amacıyla ölçeğin geliştirilme süreçlerinde de kullanılan (Drake ve diğerleri, 2015; Skowron \& Friedlander, 1998) RBSÖ ile SKE tercih edilmiştir. Diğer çalışmalardan farklı olarak bu araştırmada, uyum geçerliğinin incelenmesinde benliğin farklılaşmasına yakın bir yapı ortaya koyan otantikliğe (Wood ve diğerleri, 2008) ilişkin ölçümlerden de yararlanılmıştır. Böylece, ölçüt geçerliğinin incelenmesi amacıyla uygulanan bu üç ölçek puanlarıyla BFE-KF Türkçe formuna ait puanlar arasında korelasyonlar hesaplanmıştır. BFE-KF Türkçe formunun güvenirliği Cronbach alfa iç tutarlık katsayısı ve iki hafta süreli test tekrarı yöntemleriyle araştırılmıştır.

\section{Bulgular}

\section{Yapı Geçerliliği}

Geçerlik çalışması kapsamında, BFE-KF'nin (Drake ve diğerleri, 2015) orijinal formundaki dört bileşenli yapısı en çok olabilirlik yöntemiyle gerçekleştirilen doğrulayıcı faktör analizi ile test edilmiştir. Doğrulayıcı faktör 374 
analizinde öncelikle ölçek maddelerine ilişkin $t$ değerleri incelenmiş ve tamamının anlamlı olduğu görülmüştür. Ayrıca maddelere ilişkin hata varyansları incelenmiş ve bu açıdan bir sorun olmadığı görülmüştür. Analiz sonucunda $\chi^{2}{ }_{(163)}=558.98,(p<.001), \chi^{2} / s d=3.43, \mathrm{RMSEA}=.07, \mathrm{CFI}=.91$, IFI $=.91, \mathrm{NFI}=.88, \mathrm{NNFI}=.90$, $\mathrm{GFI}=.89$, AGFI $=.86 ; \mathrm{SRMR}=.07$ olarak bulunmuştur. Doğrulayıcı faktör analizi sonucunda elde edilen değerler, BFE-KF'nin orijinal formundaki dört bileşenli yapının Türkçe forumunda da doğrulandığı şeklinde yorumlanmıştır.

Analiz bulguları maddelere ilişkin yük değerlerinin tamamının pozitif ve anlamlı olduğunu göstermiştir. Maddelerin yük değerleri .41 ile .79 arasında değişmektedir. Maddeler içerisinde en düşük yük değeri ben pozisyonu boyutunda yer alan "hayatımda her ne olursa olsun, gerçekte kim olduğumu asla unutmayacağımı biliyorum" (madde 3) maddesine aittir. En yüksek yük değeri ise duygusal kopma boyutunda yer alan "insanlar bana çok yakınlaştığında çoğu zaman rahatsız olurum” (madde 7) maddesine aittir. BFE-KF Türkçe formunun dört bileşenli yapısına ilişkin model Şekil 1'de verilmiştir.

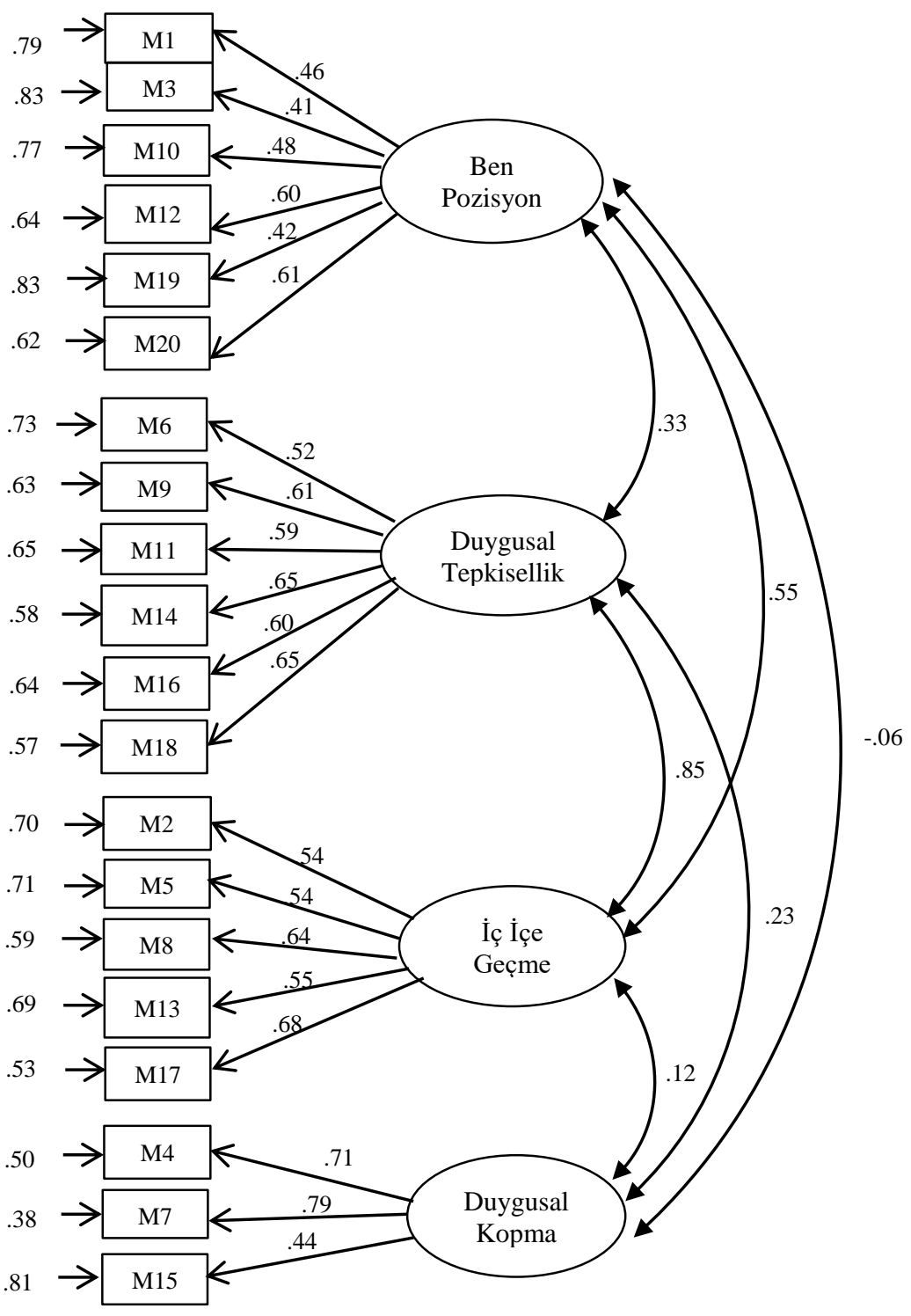

Şekil 1. BFE-KF Türkçe Formunun Dört Bileşenli Yapısı 
Yüzde 27'lik alt-üst grup arasındaki farkının manidarlı̆̆ı. BFE-KF Türkçe formunun yapı geçerliğine kanıt oluşturmak amacıyla ölçeğin ayırt edici ölçümler yapıp yapmadığı test edilmiştir. Bu amaçla \% 27'lik alt-üst grup farkının manidarlığı bağımsız örneklem $t$ testi ve çok değişkenli varyans analizi (MANOVA) ile incelenmiştir. Öncelikle, ölçek toplam puanları dikkate alınarak, benliğin farklılaşma düzeyi yüksek $(n=121)$ ve düşük $(n=$ 121) iki grup belirlenmiştir. Ardından, BFE-KF toplam puanı ile alt ölçek puanlarına ilişkin ortalamaların alt ve üst gruplarda anlamlı şekilde farklılaşıp farklılaşmadığı incelenmiştir. Levene F testi, BFE-KF toplam puanı ve alt ölçek puanlarında varyansların eşit dağıldığını göstermiştir $(p>.05)$. Yalnızca iç içe geçme boyutunda varyansların eşit olmadığı görülmüştür $(p<.05)$. Bağımsız örneklem $t$ testi sonuçları BFE-KF toplam puanlarının belirlenen üst $\left[\mathrm{x}^{-}=4.90(\mathrm{sd}=.32)\right]$ ve alt gruplarda $\left[\mathrm{x}^{-}=3.08(\mathrm{sd}=.39)\right]$ anlamlı şekilde farklılaştığını göstermiştir $\left[t_{(240)}=40.06\right]$. Alt ölçek puanlarının alt ve üst gruplarda anlamlı şekilde farklılaşıp farklılaşmadığı ise MANOVA ile test edilmiştir. MANOVA sonucunda alt ölçek puanlarının, farklılaşma düzeyi yüksek ve düşük gruplarda anlamlı şekilde farklılaştığı görülmüştür [Wilks' Lambda $=.13$, Pillai's Trace $=.87, F_{(4,237)}=401.33, p<.001, \eta^{2}$ $=.87]$. Tek yönlü varyans analizi (ANOVA) bulguları da duygusal kopma $\left[F_{(1,240)}=60.28, \mathrm{p}<.001, \eta^{2}=.20\right]$, duygusal tepkisellik $\left[F_{(1,240)}=777.96, \mathrm{p}<.001, \eta^{2}=.76\right]$, ben pozisyonu $\left[F_{(1,240)}=186.76, \mathrm{p}<.001, \eta^{2}=.44\right]$ ve iç içe geçme $\left[F_{(1,240)}=661.85, \mathrm{p}<.001, \eta^{2}=.73\right]$ alt ölçeği puanlarının alt ve üst gruplarda anlamlı şekilde farklılaştığını göstermektedir.

\section{Uyum Geçerliği}

DeVellis (2012) herhangi bir yapının teorik açıdan ilgili diğer yapılarla ilişkili olması durumunda uyum geçerliğini sağladığını belirtmiştir. Uyum geçerliğinin değerlendirilmesi amacıyla, BFE-KF Türkçe formuna ilişkin puanlarla sürekli kaygı, benlik saygısı ile otantiklik ölçeğinin alt boyutları olan dış etkileri kabullenme, kendine yabancılaşma ve otantik yaşam arasındaki ilişkiler incelenmiştir. BFE-KF Türkçe formuna ilişkin puanlarla ilişkili diğer yapılar arasında anlamlı ilişkilere ulaşılmıştır. Bu ilişkileri gösteren korelasyon katsayıları Tablo 1'de verilmiştir.

Tablo 1. BFE-KF Türkçe Formu Toplam Puan ve Alt Ölçek Puanlarına İlişkin Ortalama, Standart Sapma, Korelasyon, Uyum Geçerliği ve Güvenirlik Değerleri

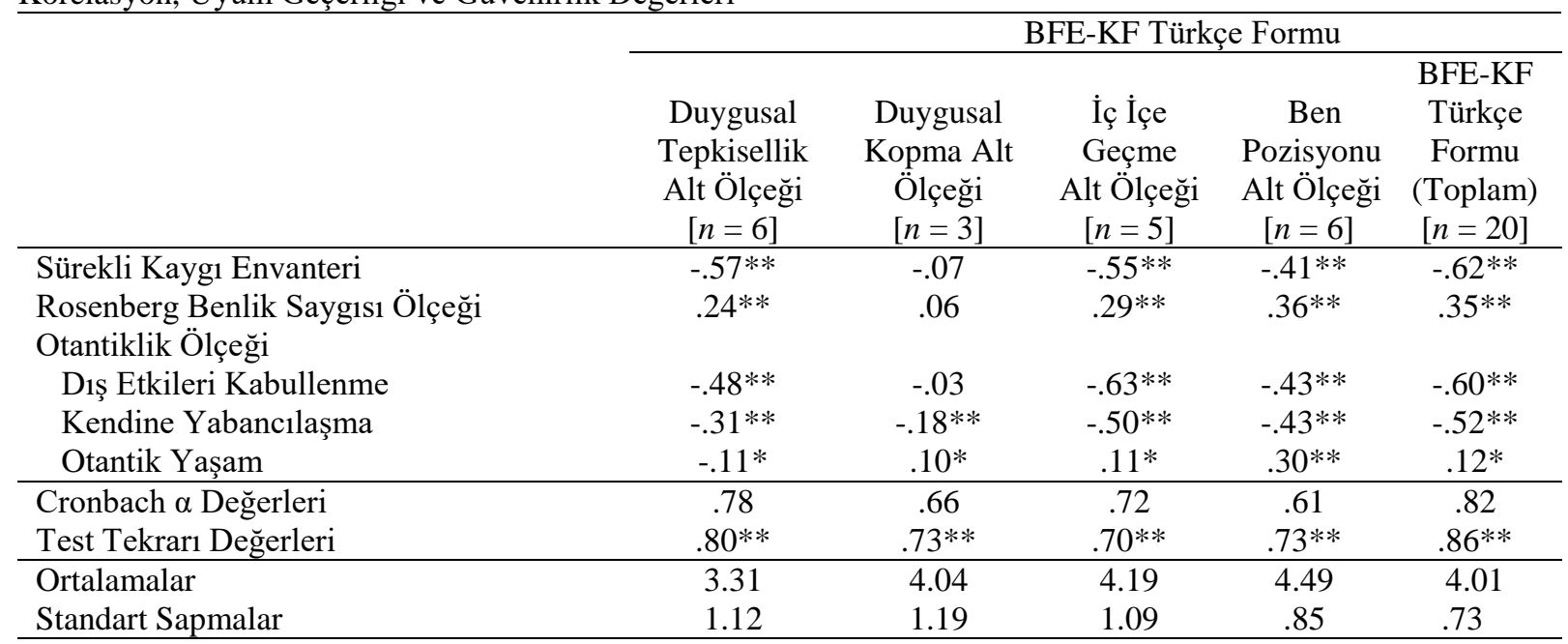

$* * p<.01 * p<.05$

\section{Güvenirlik}

BFE-KF Türkçe formu toplam puanı ile alt ölçek puanlarına ilişkin iç tutarlık ve test tekrarı güvenirlik analizler gerçekleştirilmiştir. BFE-KF toplam puanı için Cronbach alfa iç tutarlık güvenirlik katsayısı .83 olarak bulunmuştur Alt ölçeklere ilişkin iç tutarlık güvenirlik katsayıları ise .61 (ben pozisyonu alt ölçeği) ile .78 (duygusal tepkisellik alt ölçeği) arasında değişmektedir. İki hafta süreli test tekrarı güvenirlik katsayıları ise BFEKF toplam puanı için .86 olarak bulunurken, alt ölçekler için .80 (duygusal tepkisellik alt ölçeği) ile .70 (iç içe geçme alt ölçeği) arasında değişmektedir. BFE-KS'nin güvenirlik değerleri Tablo 1'de verilmiştir. 


\section{Tartışma ve Sonuç}

BFE-KF Türkçe formunun yapı geçerliğini incelemek amacıyla gerçekleştirilen analizler orijinal formdaki dört bileşenli yapının Türkçe formunda da doğrulandığını göstermektedir. Doğrulayıcı faktör analizine ilişkin $\chi^{2} / s d$ değeri, alanyazında önerilen kriter değeri karşılamaktadır (MacCallum, Brown, \& Sugawara, 1996). Benzer şekilde, uyum iyiliği indekslerinin de kabul edilebilir sınırlarda olduğu görülmektedir (Bentler, 1990; Bentler \& Bonett, 1980; Bollen, 1989; Marsh ve diğerleri, 1988). Yüzde 27'lik alt ve üst gruplar arasındaki farkın manidarlığını ölçmek maksadıyla yapılan bağımsız örneklem $t$ testi ve MANOVA sonuçları, benliğin farklılaşma düzeyi yüksek ve düşük gruplarda BFE-KF toplam puanı ve alt ölçek puanlarının anlamlı şekilde farklılaştığını ortaya koymaktadır. Tüm bu bulgular BFE-KF Türkçe forumunun yapı geçerliğini sağladığını göstermektedir.

Uyum geçerliğine ilişkin bulgular benliğin farklılaşma düzeyi ile sürekli kaygı arasında negatif yönlü ve anlamlı ilişkiler olduğunu göstermektedir. Benzer biçimde Xue ve diğerleri (2016) benliğin farklılaşmasıyla kaygı, fobiler ve panik bozukluklar arasında negatif yönlü bir ilişki olduğunu tespit etmişlerdir. Ayrıca Peleg ve Zoabi (2014) ise sosyal kaygıyla benliğin farklılaşması arasında negatif yönlü bir ilişki olduğunu söylemektedirler. Bu araştırmada benliğin farklılaşma düzeyi ile benlik saygısı arasında ise pozitif yönlü ve anlamlı ilişskiler saptanmıştır. Bu bulgular, daha önce gerçekleştirilen çeşitli araştırma sonuçlarını desteklemektedir (Drake ve diğerleri, 2015; Skowron ve Friedlander, 1998). Ancak, duygusal kopma alt ölçeğinin sürekli kayg1 ve benlik saygısı ile anlamlı bir ilişki göstermediği görülmektedir. Alanyazında bu bulguyla ilgili tutarsız bazı sonuçlar bulunmuştur. Örneğin, Skowron ve Friedlander'in (1998) ve Işık ve Bulduk'un (2014) çalışmalarında duygusal kopma ile sürekli kaygı puanları arasında anlamlı bir ilişki olduğu belirtilirken, Favre, Reynaud ve Caussidier'in (2012) çalışmasında duygusal kopma ile benlik saygısı arasında anlamlı ilişki bulunmamıştır. Duygusal kopma yaşayan bireylerde diğerlerinden uzak durma ve yakınlığın önemini inkâr etme davranışları söz konusu olduğuna göre belki de bu kişiler kendilerini korumak için öz saygı düzeylerini yüksek gösterme eğilimi içinde olabilirler. Her ne kadar bu çalışmada kaçınmacı bağlanma ile duygusal kopma arasında ilişkiler araştırılmamış olsa da, alanyazında kaçınmacı bağlanma ile duygusal kopma arasında pozitif yönde ilişkiler rapor edilmiştir (Wei, Vogel, $\mathrm{Ku}, \&$ Zakalik, 2005). Bu bulgudan hareketle, duygusal kopma yaşayan bireylerin başkalarıyla duygusal bağlarını kopardıklarında daha güçlü görünme ve kaygılarını bastırma eğilimi sergilemiş olabilecekleri söylenebilir. Öne sürülen bu görüşlerin doğruluğunu test etmek için ileride duygusal kopma ve öz saygı arasındaki ilişkide bağlanma stillerinin aracılık rolü incelenebilir. Benliğin farklılaşması puanlarıyla otantiklik ölçeği alt boyutları arasındaki ilişkilerde de benzer bir durum görülmektedir. Kendine yabancılaşma ve dış etkileri kabullenme boyutları ile benliğin farklılaşması arasında negatif yönlü anlamlı ilişkiler mevcuttur. Duygusal kopma alt ölçeği puanları ile otantikliğin boyutları arasındaki ilişkiler ise sınırlı kalmaktadır.

Genel olarak, psikolojik ölçme araçlarına ilişkin güvenirlik katsayılarının .70 ve üzerinde olması, ölçme aracının güvenirliğinin kanıtı olarak değerlendirilmektedir (DeVellis, 2012; Nunnally \& Bernstein, 1994). BFEKF toplam puanına ilişkin Cronbach alfa güvenirlik katsayısı alanyazında önerilen kriter değeri karşılamaktadır. BFE-KF'nin alt ölçeklerin iç tutarlık katsayıları ise .61 ile .78 arasında değişmektedir. İki hafta süreli test tekrarı güvenirliği değerleri de alanyazında önerilen kriter değeri karşılamaktadır. Bu da BFE-KF'nin kararlı ölçümler yaptı̆̆ını göstermektedir.

Sonuç olarak, geçerlik ve güvenirlik analizlerine ilişkin bulgular birlikte değerlendirildiğinde BFE-KF'nin geçerli ve güvenilir bir ölçme aracı olduğu görülmektedir. Bu araştırma klinik olmayan bir araştırma grubuyla yürütülmüştür. BFE-KF'nin dört bileşenli yapısı ileride gerçekleştirilecek araştırmalarda farklı danışan gruplarıyla test edilebilir. Araştırmacılar BFE-KF'yi kullanarak benliğin farklılaşması ile bağlanma stilleri, benlik kurgusu ve kaygı dışında başka psikolojik belirtilerle (örn. depresyon, umutsuzluk) ilişkilerini araştırabilirler. Böylece Türk kültüründe benliğin farklılaşmasının kavramsallaştırılmasına yönelik daha ayrıntılı açıklamalar yapılabilir. 


\section{References}

Bentler, P. M. (1990). Comparative fit indexes in structural models. Psychological Bulletin, 107, 238-246. doi:10.1037/ 0033-2909.107.2.238

Bentler, P. M., \& Bonett, D. G. (1980). Significance tests and goodness-of-fit in the analysis of covariance structures. Psychological Bulletin, 88, 588-606. doi:10.1037/0033- 2909.88.3.588

Bollen, K. A. (1989). Structural equations with latent variables. New York, NY: Wiley.

Bowen, M. (1976). Theory in the practice of psychotherapy. P. J. Guerin, Jr. (Ed.), Family therapy: Theory and practice, 42-90. New York: Garner Press.

Bowen, M. (1985). Family therapy in clinical practice. New York: Jason Aronson.

Brown, T. A. (2006). Confirmatory factor analysis for applied research. New York: Guilford.

Chabot, D. (1993). Preliminary psychometric properties of the Chabot Emotional Differentiation Scale. Unpublished manuscript, Fordham University, New York.

Choi, S. W., \& Murdock, N. L. (2017). Differentiation of self, interpersonal conflict, and depression: the mediating role of anger expression. Contemporary Family Therapy, 39(1), 21-30.

Çuhadaroğlu, F. (1986). Adolesanlarda Benlik Saygısı [Self-esteem in adolescents]. Unpublished Expertise Thesis, Hacettepe University, Faculty of Medicine, Department of Psychiatry, Ankara.

DeVellis, R. F. (2012). Scale development: Theory and applications (3rd ed.). Thousand Oaks, CA: Sage Publications

Drake, J. R., Murdock, N. L., Marszalek, J. M., \& Barber, C. E. (2015). Differentiation of self-inventory-short form: development and preliminary validation. Contemporary Family Therapy, 37(2), 101-112.

Favre, D., Reynaud, C., \& Caussidier, C. (2012). Three motivation systems but only one self-esteem? S. D. Wals \& K. Meszaros (Eds.), Handbook on psychology of self-esteem, 61-80. Nova Science Publishers.

Gladding, S. T. (2013). Counseling: A comprehensive profession. ( $7^{\text {th }}$ Edition). Pearson Higher Ed.

Haber, J. (1993). A construct validity study of a differentiation of self-scale. Scholarly Inquiry for Nursing Practice, 7(3), 165-178.

Hainlen, R. L., Jankowski, P. J., Paine, D. R., \& Sandage, S. J. (2016). Adult attachment and well-being: Dimensions of differentiation of self as mediators. Contemporary Family Therapy, 38(2), 172-183.

Hu, L. \& Bentler, P. M. (1999). Cutoff criteria for fit indexes in covariance structure analysis: Conventional criteria versus new alternatives. Structural Equation Modeling, 6(1), 1-55. doi: 10.1080/10705519909540118

Işık, E., \& Bulduk, S. (2015). Psychometric properties of the differentiation of self-inventory revised in Turkish adults. Journal of marital and family therapy, 41(1), 102-112.

Işık, E., \& Bulduk, S. (2014, April). Benliğin Ayrımlaşması Ölçeğinin üniversite öğrencileri için geçerlik ve güvenirlik çalışması [The validity and reliability study of the Differentiation of Self Inventory for university students]. Paper presented at the First Eurasian Educational Research Congress. Istanbul University Congress Center, Istanbul.

İlhan, T., \& Özdemir, Y. (2013). Otantiklik Ölçeğinin Türkçe’ye uyarlanması: Geçerlik ve güvenirlik çalışması [Adapting the Authenticity Scale to Turkish: Validity and reliability study]. Journal of Turkish Psychological Counseling and Guidance, 4 (40), 142-153.

Jöreskog, K. G., \& Sörbom, D. (1988). LISREL 7: A guide to the program and applications. Chicago, IL: SPSS Inc.

Kear, J. (1978). Marital satisfaction and attraction as a function of differentiation of self. Unpublished doctoral dissertation, California School of Professional Psychology, Fresno.

Kerr, M. E., \& Bowen, M. (1988). Family evaluation. New York: Norton. 
Krycak, R. C., Murdock, N. L., \& Marszalek, J. M. (2012). Differentiation of self, stress, and emotional support as predictors of psychological distress. Contemporary Family Therapy, 34(4), 495-515.

Lam, C. M., \& Chan-So, P. C. (2015). Validation of the Chinese Version of Differentiation of Self Inventory (CDSI). Journal of Marital and Family Therapy, 41(1), 86-101.

Lampis, J., Cataudella, S., Busonera, A., \& Skowron, E. A. (2017). The role of differentiation of self and dyadic adjustment in predicting codependency. Contemporary Family Therapy, 39(1), 62-72.

Lampis, J., Busonera, A., Cataudella, S., Tommasi, M., \& Skowron, E. A. (2017). Psychometric Properties of an Italian Version of the Differentiation of Self Inventory-Revised (It-DSI-R). Journal of Adult Development, 24(2), 144-154.

Licht, C., \& Chabot, D. (2006). The Chabot Emotional Differentiation Scale: A theoretically and psychometrically sound instrument for measuring Bowen's intrapsychic aspect of differentiation. Journal of Marital and Family Therapy, 32(2), 167-180.

Marsh, H. W., Balla, J. R., \& McDonald, R. P. (1988). Goodness-of-fit indexes in confirmatory factor analysis: The effect of sample size. Psychological Bulletin, 103, 391-410. doi:10.1037//0033-2909.103.3.391

MacCallum, R. C., Brown, M. W., \& Sugawara, H. M. (1996). Power analysis and determination of sample size for covariance structure modeling. Psychological Methods, 1, 130-149. doi: 10.1037//1082-989x.1.2.130

McCollum, E. E. (1991). A scale to measure Bowen's concept of emotional cutoff. Contemporary Family Therapy, 13(3), 247-254

Murdock, N. L. (2014). Psychological counseling and psychotherapy theories. Ankara: Nobel Academic Publishing.

Nunnally, J. C., \& Bernstein, I. H. (1994). Psychometric theory (3rd ed.). New York, NY: McGraw Hill

Öner, N., \& Le Compte, A. (1983). Durumluk - Sürekli Kaygı Envanteri el kitabı [State - Trait Anxiety Inventory Handbook]. İstanbul: Boğaziçi University Publications.

Peleg, O. (2002). Bowen theory: A study of differentiation of self and students' social anxiety and physiological symptoms. Contemporary Family Therapy, 25, 355-369

Peleg, O., \& Zoabi, M. (2014). Social anxiety and differentiation of self: A comparison of Jewish and Arab college students. Personality and Individual Differences, 68, 221-228.

Rosenberg, M. (1965). Society and the adolescent self-image. Princeton: Princeton University Press.

Ross, A. S., Hinshaw, A. B., \& Murdock, N. L. (2016). Integrating the relational matrix: attachment style, differentiation of self, triangulation, and experiential avoidance. Contemporary family therapy, 38(4), 400-411.

Sandage, S. J., \& Jankowski, P. J. (2013). Spirituality, social justice, and intercultural competence: Mediator effects for differentiation of self. International Journal of Intercultural Relations, 37(3), 366-374.

Sandage, S. J., Jankowski, P. J., Bissonette, C. D., \& Paine, D. R. (2017). Vulnerable narcissism, forgiveness, humility, and depression: Mediator effects for differentiation of self. Psychoanalytic Psychology, 34(3), 1-11

Schmitt, D. P., \& Allik, J. (2005). Simultaneous administration of the Rosenberg Self-Esteem Scale in 53 nations: Exploring the universal and culture-specific features of global self-esteem. Journal of personality and social psychology, 89(4), 623.

Skowron, E. A., \& Friedlander, M. L. (1998). The differentiation of self-inventory: Development and initial validation. Journal of Counseling Psychology, 45, 235-246. doi:10.1037/0022-0167.45.3.235.

Skowron, E. A., \& Schmitt, T. A. (2003). Assessing interpersonal fusion: Reliability and validity of a new DSI fusion with others subscale. Journal of Marital and Family Therapy, 29(2), 209-222.

Skowron, E. A., \& Dendy, A. K. (2004). Differentiation of self and attachment in adulthood: Relational correlates of effortful control. Contemporary Family Therapy, 26(3), 337-357. 
Sloan, D., \& van Dierendonck, D. (2016). Item selection and validation of a brief, 20-item version of the Differentiation of Self Inventory-Revised. Personality and Individual Differences, 97, 146-150.

Spielberger, C. D., Gorsuch, R. L., \& Lushene, R. E. (1970). Manual for the State-Trait Anxiety Inventory. Palo Alto, California: Consulting Psychologists Press.

Wei, M., Vogel, D. L., Ku, T. Y., \& Zakalik, R. A. (2005). Adult attachment, affect regulation, negative mood, and interpersonal problems: The mediating roles of emotional reactivity and emotional cutoff. Journal of Counseling Psychology, 52(1), 14-24.

Wood, A., Linley, P., Maltby, J., Baliousis, M. \& Joseph, S. (2008). The authentic personality: A theoretical and empirical conceptualization and the development of the authenticity scale. Journal of Counseling Psychology, 55, 385-399.

Xue, Y., Xu, Z. Y., Zaroff, C., Chi, P., Du, H., Ungvari, G. S., ... \& Xiang, Y. T. (2016). Associations of differentiation of self and adult attachment in individuals with anxiety-related disorders. Perspectives in Psychiatric Care. Doi: 10.1111/ppc.12200 